Ganna Karcheva,

Dr.Sc., Professor, Banking University, Ukraine

ORCID ID, 0000-0002-5897-8445

email: anna.karcheva@gmail.com

Natalia Shvets,

Dr.Sc., Professor, Banking University, Ukraine

ORCID ID, 0000-0003-0915-9918

email: shvetzn@ubs.edu.ua

Karina Dalgic,

Banking University, Ukraine

ORCID ID, 0000-0001-7015-6324

email:k.grabarchuk@gmail.com

Nataliya Dalevska,

Dr.Sc., Associate Professor, Institute for International Cooperation Development, Poland

ORCID ID, 0000-0002-0074-497X

email: dalevskanm@gmail.com

Correspondence author: k.grabarchuk@gmail.com

\title{
INNOVATIVE APPROACHES TO THE ASSESSMENT OF BANKING COMPETITION IN UKRAINE IN TERMS OF DIGITAL TRANSFORMATION
}

\begin{abstract}
The article considers the issues on banking competition interaction, the banking system's stability and efficiency. This research aims to conduct a comprehensive assessment of the banking competition that consists of structural and non-structural methods under the institutional changes' impact. The paper presents how this influences the banking system of Ukraine through its reformation in the banking competition level and how it interacts with indicators of stability and efficiency of the banks. In this study's frame, the authors applied a developed approach to the modified model of Panzar-Rosse regarding the banking activity in Ukraine after it has been rebooted and "cleansed of». The systematization of the scientific background and approaches to assessing the level of banking competition in Ukraine noted that, generally, native authors used only one of the methods to assess the level of competition in the banking industry of Ukraine. Besides, their studies focused on the pre-crisis period, when these innovations hadn't significantly affected the banks' activity changes. The importance of solving this scientific problem is identifying problems in the banking system and taking measures to eliminate them, using the comprehensive assessment of the banking competition level, considering the explanatory indicators of the banks' stability. This issue became critical after a significant reduction in the number of banking institutions in Ukraine and the change in the institutional structure of the banking system of Ukraine under the influence of financial innovations. The study into assessing the level of competition in the banking market of Ukraine is carried out in the following logical sequence: 1) considering the studies on the given subject; 2) describing the existing methods for assessing competition in the banking industry; 3) describing the proposed modified methods of the assessing the level of banking competition; 4) providing proposals regarding the improving banking competition in Ukraine. The study's period is 2015-2019. The research object is the banking system of Ukraine. The article presents an empirical analysis of the current level of competition in the banking market of Ukraine. The findings showed that the banking sector of Ukraine is characterized by monopolistic competition, which is characterized by increasing concentration in the market of the state-owned banks. The study empirically confirms and theoretically proves that some Ukrainian banks have increased their market share due to a decrease in the number of banks in recent years due to the influence of digital transformation. The results of this study could be beneficial for the use of proposed innovative approaches to assessing the level of banking
\end{abstract}

Cite as: Karcheva, G., Shvets, N., Dalgic, K., \& Dalevska, N. (2021). Innovative Approaches to the Assessment of Banking Competition in Ukraine in Terms of Digital Transformation. Marketing and Management of Innovations, 1, 181-195. http://doi.org/10.21272/mmi.2021.1-14 
G., Karcheva, N., Shvets, K., Dalgic, N., Dalevska. Innovative Approaches to the Assessment of Banking Competition in Ukraine in Terms of Digital Transformation

competition in Ukraine in the future, for the bank owners (including small ones), also on proposals for the perspective development of neo-banks in Ukraine, in which there is a need not only for the banking system but also for the users of banking services.

Keywords: banking system; competition; innovations; market; stability.

Introduction. The banking system is an integral and significant part of the country's economy. The state of the banking system and its efficiency affect the development of the economy's real sector by providing lending by banks to the expanded reproduction, including corporate banking customers and the public, including mortgages at reasonable interest rates commissions.

It is well known that microeconomics has a direct relationship between the level of competition in any market and the level of quality, efficiency, price of products and goods in this market, the integrity of competitors, and the emergence of incentives to improve their practices. Healthy competition «helps make the financial sector more efficient» (OECD, 2011). Akins et al. (2014) found that «banks that face more competition earn lower interest margins and make investments with less risk». Amidu and Wolfe (2013) supported the positive impact of competition on banks' stability, as «diversification within both interest and non-interest income received by banks is increasing». Besides, in the study (Bank of England, n.d.) the competition was supported because there were not enough banks before the financial crisis and some banks were «too big to be liquidated». Hence, the proper level of competition in the banking sector ensures the banking system's stability. However, «excessive competition could increase some risks», such as asymmetric information and moral hazard (Reserve bank of Australia, 2014). Thus, Titko et al. (2015) did not find empirical confirmation of the hypothesis of a positive competition impact in the Latvian banking sector on a level to give bank stability.

The importance of studying the level of banking competition shows the impact on the efficiency and stability of banks and banking systems. In the studies (Vives, 2016; Sinki, 2019; Bikker et al., 2010; Cetorelli and Gambera, 2001), the authors found a link between competition level and the development of the banking system. It is believed that a high level of competition characterizes developed countries. In contrast, a low level of competition characterizes the countries with a low economic development level (including Ukraine). However, Vives (2016) noted that each country has its own optimal competition level, ensuring stable banking.

It is important to achieve an optimal competition level to maintain stability and efficient development within the banking system. Maintaining regulatory processes is important for a competitive environment and banking competition. In turn, that is possible, providing an objective measurement of competition and assessing factors that affected it.

Vasylieva (2015) and Didenko et al. (2018) considered the model of H-Statistics (Panzar-Rosse) for the banking sector of Ukraine from 2005 to 2016. It showed that during the periods of the financial crises of 2008-2009 and 2014-2016, the values of H-Statistics were negative. Therefore, there was monopolistic competition in the Ukrainian banking market.

Another Ukrainian scientist Leonov (2009) assessed the competition levels in the banking sector of Ukraine for the pre-crisis period using the Modesto Barroso model (1999).

Didenko et al. (2018) used the Panzar-Rosse model, or H-Statistics, (1987) to assess the level of competition in the deposit market of Ukraine. Quarterly data of the banks' financial performance in Ukraine for 01.01.2005-01.04.2016 were used as the input data. This study's result was the observation of the monopolistic competition with parts of the deviation to absolute monopoly or oligopoly.

Zherdetska and Tatarova (2009) assessed the level of competition in the banking market of Ukraine according to the Panzar-Rosse model for 2007. It was found that the banking market of Ukraine corresponds to monopolistic competition. 
G., Karcheva, N., Shvets, K., Dalgic, N., Dalevska. Innovative Approaches to the Assessment of Banking Competition in Ukraine in Terms of Digital Transformation

Thus, the studies conducted by the researchers in Ukraine regarding the condition of the competitive environment and the banking competition level, usually considered the pre-crisis period, did not assess the impact of the institutional changes in the banking system in recent years.

Therefore, over the past five years, there had been a tendency to reduce the total number of banks significantly. That was due to the loss of solvency of small and large banks due to high risks in their activities: poor loan portfolios, significant amounts of lending to the related parties, and banks' bankruptcy. At the same time, it should be noted that as a result of the emergence and active implementation of various innovations in the banking system, the branch network of the banking system of Ukraine have also reduced and changed primarily due to the development of remote services, including online-banking (Figure 1).

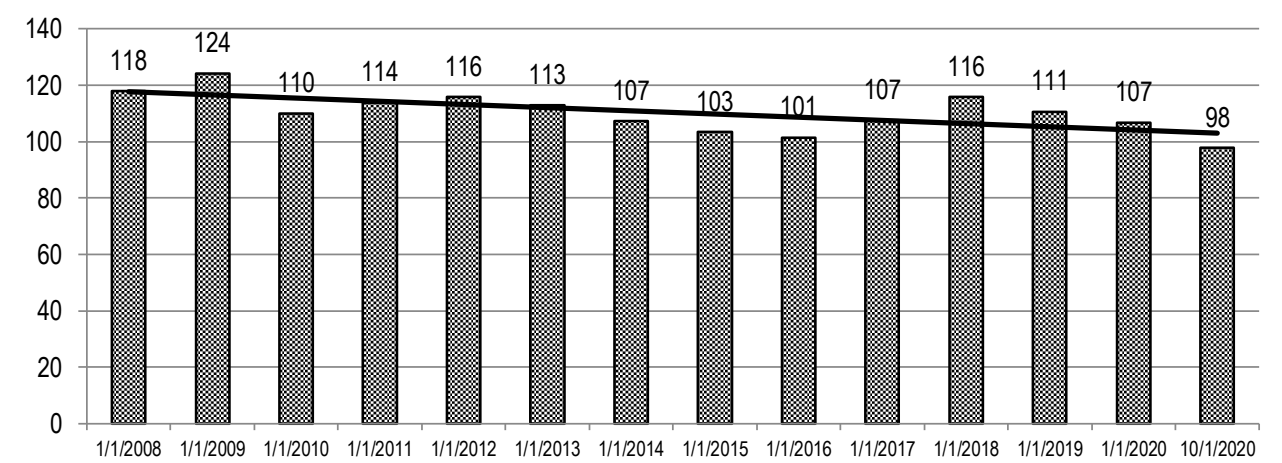

Figure 1. Dynamics of the ratio of the number of divisions to the number of operating banks in Ukraine, 2008-2020

Sources: developed by the authors using the NBU database.

Therefore, the level of competition in the banking market of Ukraine has decreased significantly due to the massive liquidation of the banking institutions and the structural changes in the banking system of Ukraine. According to the innovative approaches, the authors' searching activities intensified on the assessment of the current level of the competition in the banking market of Ukraine. There are suggestions for possible ways to increase the competition level. In turn, it would contribute not just to the innovative development of the products and services but also to improving the market players' practice by increasing their level of stability, liquidity, and reputation.

Literature review. There are two main approaches to measure the competition level: structural and non-structural. The traditional theory is based on the structural models that assume a relationship between the industry structure and the market share. Non-structural models directly measure the behavior of the market participants. That determines the degree of competition. Non-structural models allow analyzing the competition level based on pricing in banks. In particular, non-structural models are based on the theory of equilibrium market, according to which pricing - on cost (markup pricing).

In the studies (Berger et al., 2004; Berger et al., 1989; Bikker et al., 2002; Casu and Girardone, 2006; Duncan and Langrin, 2004), the authors noted that the structural models are based on two main hypotheses: "Structure-conduct-performance (SCP)» and the opposite hypothesis of efficient structure (Efficient Structure - ES). According to the SCP hypothesis, there is a relationship between the industry structure (concentration, number of banks), their behavior, profits, and market share level. The larger the number of banks will lead to the setting of interest rates on loans and deposits at a competitive level, which minimizes the individual banks' market power. The SCP hypothesis is tested by using the equation of the 
G., Karcheva, N., Shvets, K., Dalgic, N., Dalevska. Innovative Approaches to the Assessment of Banking Competition in Ukraine in Terms of Digital Transformation

dependence of the performance of the bank on market concentration (concentration ratio $\mathrm{n}$ - banks or Herfindahl-Hirschman Index):

$$
P_{i j t}=a_{0}+a_{1} C R_{j t}+\sum \gamma_{k} X_{k i j t}+\varepsilon_{i j t}
$$

where $\mathrm{P}_{\mathrm{ijt}}$ - the profit of the bank $\mathrm{i}$ in the market at time $\mathrm{t}$ (also the interest rate on loans or deposits of bank $i$ in market $j$ at time $t$ could be used); $C_{\mathrm{jt}}-$ a variable that measures competition in the market $j$ at time $\mathrm{t}$; $\mathrm{X}_{\mathrm{kij}}-\mathrm{k}$-dimensional vector of variables that affects the bank's profit.

According to the SCP hypothesis, the coefficients a should be greater than 0, i.e., the higher market concentration means the higher market power and the higher bank's profit. Banks could set the more concentrated market, the higher interest rates on loans, and lower interest rates on deposits. Banks' greater market power, i.e., high concentration, is the cause of banks' non-competitive behavior. These models' market structure is assumed to be exogenous (Zherdetskaya, 2009; 2016).

Structural models also use the efficient structure (ES) hypothesis. There is a direct relationship between the market position and the financial performance: banks with high operational efficiency tend to have lower costs and higher profits. By increasing their efficiency, banks strengthen their market positions by increasing their market share.

$$
\Pi_{i j t}=a_{0}+a_{1} C R_{j t}+a_{2} M S_{i j t} \sum \gamma_{k} X_{k i j t}+\varepsilon_{i j t}
$$

where $\mathrm{MS}_{\mathrm{ijt}}$ - the market share of the bank.

According to the SCP hypothesis $a_{1}>0$, the efficiency hypothesis (ES) requires that $a_{2}>0$. (Demsetz., 1973; Peltzman, 1977). It stands to note that non-structural models measure the degree of the competition by assessing the bank's behavior in the market, not through the exogenous market structure (concentration indicators). The structural approach determines the degree of banking competition through its structure parameters, such as the level of the concentration (usually the share of assets of the three or five largest banks in the total banking sector) and various indicators. The competitive environment affects the behavior of banks. At the same time, a change in market participants' behavior causes changes in the competitive environment. In turn, it could lead to a change in the type of competition. Given the complexity and ambiguity of the concept of «competition», it is difficult to assess by one method or several indicators. To obtain an objective assessment of the level of competition and the competitive environment's condition, it is important to comprehensively assess the level of competition in the banking market of Ukraine by structural and non-structural models. Besides, considering the formation of an economically sound and accurate information model for calculations, taking into account banking systems in countries with emerging markets and bifurcation processes are traced and consider institutional changes under digital technologies' influence.

Methodology and research methods. Among the competition level's structural indicators, the concentration of the total assets of the 3 largest banks in Ukraine and the Herfindahl-Hirschman Index $(\mathrm{HHI})$ were used. That considers the number of banks and the inequality of their market position and characterizes the level of monopolization. The value of the coefficient decreases with the increasing number of banks and increases with strengthening the inequality between them for any number of them (Karcheva, 2016). The higher the level of the market concentration, the higher the HHI value. The Herfindahl-Hirschman concentration index varies from zero (maximum market competitiveness) to 10,000 (market monopoly). In the case of a pure monopoly, when the industry includes one firm, the index is 10,000 . As a rule, the shares of participants in the banking market are determined by assets, loans, and deposits. In general, there are three degrees of market concentration: 
G., Karcheva, N., Shvets, K., Dalgic, N., Dalevska. Innovative Approaches to the Assessment of Banking Competition in Ukraine in Terms of Digital Transformation

- weak concentration if the value of the $\mathrm{HHI}$ index is less than 1,000 ;

- average level of concentration, if the value of the HHI indicator does not exceed from 1,000 to 1,800;

- high concentration if the $\mathrm{HHI}$ value exceeds 1,800 .

Some researchers (Beck, 2008; Feldkircher and Sigmund, 2017) believe that concentration ratios (such as market share ratio or Herfindahl-Hirschman index), commonly used as indicators of the competitive environment, are not always the objective indicators of competition, as they do not reflect the real market situation. Moreover, they are weakly correlated with the competitive behavior of banks. Therefore, it is proposed to further analyze the level of competition in the banking market of Ukraine according to the non-structural models. In such models, the competitive environment is determined not by the market structure but by market participants' strategic decisions. The non-structural models measure competition without the use of clear information on the structure of the market. It is based on obtaining a market impact assessment based on observations of bank behavior. For measuring the competition level, the non-structural approach uses such indexes as Lerner's index (Lerner, 1934), Boone's indicator of «effective competition» (Boone, 2000), indicators of price and the quantitative reaction of the bank to competitors, developed by Bresnahan (1982) and Lau (1982), indicators of the bank interchangeability for consumers (Barros and Mudesto, 1999), H-Statistics or the Panzar-Rosse approach (Panzar and Rosse 1987 ) and other. Among the above non-structural models, the article calculated Lerner's index and HStatistics for the banking market of Ukraine. Lerner's index is calculated based on information about the activities of an individual bank. It measures its power in the market depending on the excess over marginal costs. Besides, it could set interest rates on deposits or loans. The following formula calculates the Lerner index:

$L=\frac{P-M C}{P}$

where $\mathrm{L}$ - the Lerner index, $\mathrm{P}$ - interest rates on deposits or loans; $\mathrm{MC}$ - marginal cost.

As the value of $\mathrm{P}$ (price), the value of the average interest rate on loans was used because the main interest income for Ukrainian banks is interest income on loans:

$$
L=\frac{\text { Interest income }}{\text { Loans and receivables }}
$$

As the value of the marginal costs (MC), the value of the borrowed funds' average cost was used, weighted by the cost of reserves and administrative costs. That was because the Lerner index must also include an adjustment for the credit risk, i.e. when calculating marginal costs must include not only general administrative costs but also the costs of the credit risk coverage (Beck, 2008):

$$
M C=\frac{\text { Interest expenses }+ \text { deduction to reserves }+ \text { Administrative and other costs }}{\text { Customer deposit }}
$$

The Lerner index value could be between 0 and $1(0 \%$ and $100 \%)$. The higher the Lerner index, the stronger influence of an individual bank and, consequently, the lower the competition level. It is worth noting that there is no consensus among the scientists and practitioners on the best indicator for assessing the competition level. Moreover, sometimes different studies for one country and one study's period get different conclusions about the competition level and dynamics. As a rule, the bank's assets or loan portfolio are used, but the bank's deposit portfolio is used in some cases. Non-structural models assume that a bank's performance indicators are used to approximate competition. That assesses the competition level in the banking sector. Non-structural methods of the competition assessment include the Panzar- 
G., Karcheva, N., Shvets, K., Dalgic, N., Dalevska. Innovative Approaches to the Assessment of Banking Competition in Ukraine in Terms of Digital Transformation

Rosse model (H-Statistics). It worth noting that some scientists believe that this model gives more accurate results (Skorlupyna, 2015; Zherdetskaya, 2009). Panzar-Rosse's model is based on the assumption that banks operate in the long-term equilibrium. The following parameters are observed: the banks interact with each other, influencing each other's actions, the elasticity of demand exceeds 1 , a homogeneous cost structure is maintained. For banks, $\mathrm{H}$-Statistics is defined as the bank's interest income elasticity at threefactor prices: the cost of funding, staff costs, and other costs. The classic model of Panzar-Rosse is:

$$
\ln (R)=a+\beta \ln (F I P)+\gamma \ln (E T A)+\delta \ln (T A)+\varepsilon
$$

where $\mathrm{R}$ is the bank's income (dependent variable); FIP - variables that reflect cost prices in the banks' activities; ETA - variables that describe specific factors; TA - total assets; $\varepsilon$ - the remainder of the model.

The value of $\mathrm{H}$-Statistics is defined as the sum of the coefficients $\beta$ for the variables included in the FIP component. If $\mathrm{H} \leq 0$, there is a monopoly in the market, $0<\mathrm{H}<1-$ monopolistic competition; $\mathrm{H}=1-$ perfect competition. That is the classic model used by most scientists. Ukrainian scientists have widely used the Panzar-Rosse model to assess the competition level for various years. Thus, Zherdytska (2009) built a model in which the asset return was taken as the effective value. The accuracy of that model was quite high $(\mathrm{R} 2=0.884)$.

Another Ukrainian scientist Hirna (2014) performed the calculations according to the Panzar-Rosse model for 2007 and 2011. The operating income was taken as the resultant value; the coefficient of determination was 0.98. Hirna (2014) used the specifications of the Panzar-Rosse model proposed in Bikker et al. (2007) to compare the possible changes in the Ukrainian banking market's competitive characteristics. H-Statistics for 2007 amounted to 0.567; for $2011-0.377$. The obtained results showed that the competition level in the banking sector of Ukraine and the countries of the European Union were characterized as monopolistic competition. According to this model, the values of $\mathrm{H}$-Statistics for Ukraine were much lower than the Eurozone average, which in 2007 was 0.643. It stands to note that Hirna (2014) includes only two types of expenses in the FIP component: interest expenses and administrative expenses, without allocating labor costs and the formation of reserves to cover the risks of active operations. Notably, banking competition is one of the important factors in ensuring the banking system's stability. Therefore, the cost of forming reserves to cover the risks is proposed to include the modified Panzar-Rosse model, which has a significant part of banks' costs in recent years and is a necessary condition for their financial security and liquidity level.

As the level of formation of provisions for risk coverage and liquidity level, such variables were included in the modified Panzar-Rosse model. Capitalization is the necessary condition for the financial stability and security of the banks. Consequently, banks' competition level is determined by banks' scale, cost efficiency, and stability.

Given the above, the following indicators were included in the modified Panzar-Rosse model:

- to the FIP component: the value of the liabilities; the level of formation of reserves for the active operations; salary costs of the bank employees; other administrative expenses and other expenses (the last three indicators were calculated concerning assets);

- to the ETA component: the level of capitalization and liquidity that ensure the stability of the bank. Notably, the exclusion of liquidity from the model led to a decrease in the $\mathrm{H}$-Statistics value, which indicates this explanatory variable's feasibility in the Panzar-Rosse model.

For building and analyzing the above models, the indicators of financial performance of all banks in Ukraine were used for this study's period, taken from the official website of the National Bank of Ukraine (NBU). 
G., Karcheva, N., Shvets, K., Dalgic, N., Dalevska. Innovative Approaches to the Assessment of Banking Competition in Ukraine in Terms of Digital Transformation

Results. The theoretical justification for using concentration as a measure of competition is reduced to the so-called structural-behavioral paradigm. Reducing the number of banks and increasing their size leads to cartels, quasi-monopolistic behavior of the market participants, and more. As of 1 August 2020, the concentration of total assets of the 3 largest banks in the banking system of Ukraine was $51 \%$. All three banks are state-owned (NBU). It stands to note that the banking system's level of concentration is growing rapidly in recent years. Thus, as of 1 January 2008, the share of the total assets of the 3 largest banks in Ukraine was 23.1\%. Besides, all of them were private banks (Privatbank, Raiffeisenbank Aval, and Ukrsibbank (NBU)). That may be a reason for the decline in the competition in the banking services market in the future or a promising vector for the development of the institutional system of the banking system of Ukraine.

After all, there are high concentrations in the banking services market of the 3 and 5 largest banks in many countries worldwide. For example, the concentration of total assets of the 5 largest banks in the banking system of the Netherlands is $89 \%$, Sweden $-76 \%$, Spain - $65 \%$, France $82 \%$, Luxembourg $69 \%$, Canada $-81 \%$, Australia $-80 \%$. In the US, this figure is $43 \%$, in Japan $-51 \%$, Brazil $82 \%$, India $36 \%$, China 37\%, Korea 62\%, Mexico 70\%, Singapore 42\% (CGFS, 2018). Simultaneously, in large developed countries of Western and Central Europe, banking assets' concentration is lower than in Ukraine. In Belgium, it reaches 48\%, Italy - 43\%, Great Britain - 48\%, in Germany - 35\% (CGFS, 2018). The concentration of bank assets is often used to assess the competition. However, in practice, the concentration of assets is not always a fairly accurate indicator. For example, in Canada, where the share of assets of the top five banks exceeds $80.0 \%$, the degree of competition is quite high because other financial institutions create fierce competition for the banks, such as credit unions and mutual funds.

According to the World Bank research, traditional concentration indicators reflect only the market structure and do not have a clear relationship with competition (Beck, 2008). For example, an increase in the banking sector concentration could be observed simultaneously with an increase in competition in the banking sector's consolidation (Beck, 2008). Thus, structural indicators (indicators of concentration) do not give a complete picture of the degree of competition in the banking sector, its stability over time. Another disadvantage of the market concentration indicator is its low sensitivity to different distributions of shares between competitors. Therefore, in practice, the Herfindahl-Hirschman Index (HHI) has been increasingly used in recent years. Calculating the Herfindahl-Hirschman Index for the Ukrainian banking market for 2015-2020 (Figure 2) shows that the concentration of Ukrainian banking sector assets is 01.01.2018 was high (the value of the Herfindahl-Hirschman Index - 2630). Still, since 1 January 2019, the value of this indicator has decreased significantly. Thus, the concentration of the assets of the banking sector of Ukraine remains at the average value. The concentration of customer loans and equity is low. However, the value of individuals' concentration of deposits in recent years is close to high (01.01.2019. 1707, 01.08.2020 - 1564).

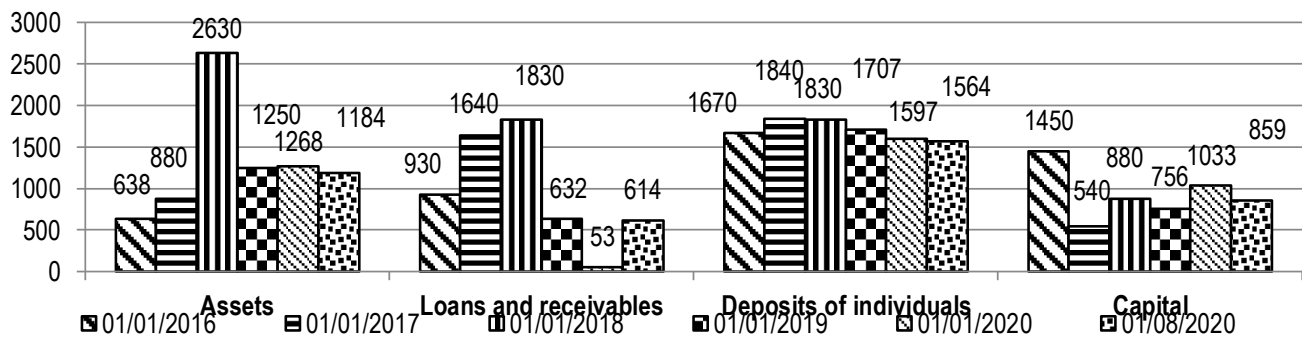

Figure 2. The value of the Herfindahl-Hirschman Index for the Ukrainian banking sector, for 20152020

Sources: developed by the authors based on the NBU database. 
G., Karcheva, N., Shvets, K., Dalgic, N., Dalevska. Innovative Approaches to the Assessment of Banking Competition in Ukraine in Terms of Digital Transformation

Consequentially, during the banking system reformation period, period of «cleansing» of troubled banks, there were structural changes in the banking sector, as evident by the Herfindahl-Hirschman Index's value, the banking market moved from low to medium competition level.

In the calculations of the non-structural indicator (Lerner index) for the banking system of Ukraine, some banks, and sometimes all banks in some years (2017), had a relative value of the indicator. It may indicate unprofitable activities, increased risks, unprofessional financial management. In some cases, its value was higher than 1 , which may indicate the banks' maximization while minimizing their marginal costs. For obtaining more accurate results, the study considers those values of the Lerner index that are not included in the interval $[0 ; 1]$ (Table 1).

Table 1. The results of the calculation of the Lerner index for the Ukrainian banking system, 2012-

\begin{tabular}{llllllll}
\multicolumn{7}{c}{$\mathbf{2 0 1 9}$} \\
\hline & 2012 & 2013 & 2014 & 2015 & 2016 & 2018 & 2019 \\
\hline Average & 0,37 & 0,52 & 0,50 & 0,47 & 0,34 & 0,37 & 0,46 \\
1at quartile (25\%) & 0,19 & 0,62 & 0,36 & 0,47 & 0,29 & 0,50 & 0,41 \\
Median & 0,19 & 0,62 & 0,36 & 0,47 & 0,29 & 0,50 & 0,41 \\
2nd quartile (75\%) & 0,46 & 0,76 & 0,82 & 0,75 & 0,49 & 0,52 & 0,61 \\
Number of banks within the [0;1] & 9 & 7 & 7 & 6 & 4 & 7 & 67 \\
interval of Lerner index & 175 & 180 & 158 & 111 & 99 & 77 & 75 \\
Total number of banks being tested & 175
\end{tabular}

Sources: developed by the authors based on the NBU database.

Figure 3 shows the dynamics of the average value of the Lerner index.

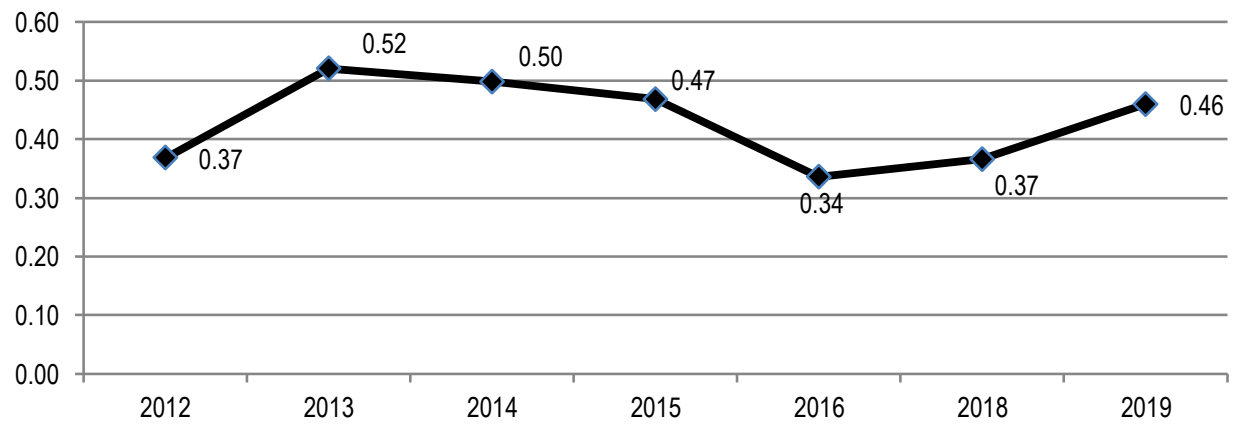

Figure 3. The dynamics of the average value of the Lerner index for the Ukrainian banking market, 2012-2019

Sources: developed by the authors based on the NBU database.

After the «cleansing» of unscrupulous market players' banking system, the Lerner index value in 2018 was 0.37 and in $2019-0.46$. That indicates the excessive power of the individual banks is not typical for the Ukrainian banking market. Still, the level of competition decreased due to the state banks' increased power, the banks of foreign banking groups, and some private banks with aggressive gaming policies in Ukraine (Table 2). According to the structural (concentration index) and non-structural (Lerner index), the current competition model is limited by a high share of the state-owned banks. Many experts suggested privatizing the state-owned banks as a measure needed to increase the competition level in the banking market. 
G., Karcheva, N., Shvets, K., Dalgic, N., Dalevska. Innovative Approaches to the Assessment of Banking Competition in Ukraine in Terms of Digital Transformation

Table 2. Banks with the highest value of the Lerner index in 2019

\begin{tabular}{clc}
\hline Group of banks & \multicolumn{1}{c}{ Name of the bank } & $\begin{array}{c}\text { Value of the } \\
\text { Lerner index }\end{array}$ \\
\hline \multirow{3}{*}{ Banks with state } & JSC CB «PrivatBank» [AT KB «PryvatBank»] & 0.83 \\
share & Oschadbank JSC [AT «Oshchadbank»] & 0.68 \\
& JSC «Ukreximbank» [AT «Ukreksimbank»] & 0.48 \\
& JSB UKRGASBANK [AB «UKRHAZBANK»] & 0.65 \\
& Raiffeisen Bank Aval JSC [AT «Raiffaizen Bank Aval»] & 0.58 \\
& JSC «UKRSIBBANK» [AT «UKRSYBBANK»] & 0.61 \\
& CITIBANK JSC [AT «SITIBANK»] & 0.93 \\
Banks of foreign & JSC «ING Bank Ukraine» [AT «INH Bank Ukraina»] & 0.67 \\
banking groups & JSC «PRAVEX BANK» [AT «PRAVEKS BANK»] & 0.62 \\
& Deutsche Bank DBU JSC [AT «Doiche Bank DBU»] & 0.84 \\
& SEB CORPORATE BANK JSC [AT «SEB KORPORATYVNYI & 0.86 \\
& BANK»] & 0.78 \\
& JSC «CREDIT EUROPE BANK» [AT «KREDYT YEVROPA BANK»] & 0.66 \\
& JSC «BTA BANK» [AT «BTA BANK»] & 0.78 \\
& JSC «FIRST INVESTMENT BANK» & 0.69 \\
Banks with private & JSC «City Bank» [AT «Misto Bank»] & 0.72 \\
capital & JSC «ALTBANK» [AT «ALTBANK»] & 0.71 \\
& JSC «UNEX BANK» [AT «lUNEKS BANK»] & 0.89 \\
& JSC «BANK AVANGARD» [AT «BANK AVANHARD»] & 0.98 \\
& PJSC «FAMILY BANK» [PrAT «BANK FAMILNYI»] & 0.78 \\
\hline
\end{tabular}

Sources: developed by the authors based on the NBU database.

However, it is unlikely that the privatization of state-owned banks would lead to the increased competition. There is the suggestion that privatized state-owned banks are likely to start a more aggressive expansion for the sole purpose of maximizing profits. Instead, state-owned banks contribute to achieving the strategic economic goals and perform several social functions. Besides, it should be noted that reaching a certain level of competition begins to have a destructive effect on the banking system's stability. Therefore, the presence of state-owned banks in the banking system of Ukraine helps to increase public confidence. However, the high share of the state-owned banks in the banking services market of Ukraine leads to a decrease in the competition, low-quality loan portfolios, and a high share of non-performing loans formed in the banking sector, threatening the financial stability of the country and hinders the economic financing. Concerning another non-structural model (H-Statistics), it should be noted, that today there is no single point of view on the performance variable in the Panzar-Rosse model. Some authors use interest income as an effective variable, others - operating income or return on assets. Three variants of calculations with different performance variables were performed while developing this model according to the general population's data of 01.01.2020. Table 3 presents data on coefficients of determination and $\mathrm{H}$-Statistics for models with different dependent variables.

Table 3. H-Statistics and the coefficients of the determination for models with different dependent variables

\begin{tabular}{lcc}
\hline Dependent variable $(\mathbf{Y})$ & Coefficient of determination $\left.\mathbf{R}^{2}\right)$ & H-statistics \\
\hline Net gross income & 0,647 & 0,414 \\
Interest income & 0,974 & 0,309 \\
Operating income & 0,975 & 0,380 \\
\hline
\end{tabular}

Sources: developed by the authors based on the NBU database. 
G., Karcheva, N., Shvets, K., Dalgic, N., Dalevska. Innovative Approaches to the Assessment of Banking Competition in Ukraine in Terms of Digital Transformation

The developed Panzar-Rosse model for the banking system of Ukraine for 01.01 .2020 is as follows:

$$
\begin{aligned}
& Y=-3,344+1,046 X_{1}+0,105 X_{2}+0,168 X_{3}-0,092 X_{4}+0,138 X_{5}+0,060 X_{6}-0,040 X_{7} \\
& R^{2}=0,974
\end{aligned}
$$

where $Y$ - operating income of the banks; $X_{1}$ - assets of the banks; $X_{2}$ - deductions to reserves to cover the risks; $X_{3}$ - staff salaries; $X_{4}$ - other administrative expenses and other expenses; $X_{5}-$ the cost of liabilities; $X_{6}$ - level of capitalization; $X_{7}$ - level of liquidity.

The value of $\mathrm{H}$-Statistics is equal to $0.319(0.105+0.168-0.092+0.138)$.

The studies using the Panzar-Rosse model showed that despite a significant reduction in the number of banks, H-Statistics decreased slightly compared to the pre-crisis period. Besides, it is in the range of $(0.309 \div 0.414)$, which indicates monopolistic competition in the banking system of Ukraine. At the same time, it is worth noting the dynamic growth of the Herfindahl-Hirschman Index over the past five years due to the rapid growth from state-owned banks' influence, particularly due to the nationalization of Privatbank. The Herfindahl-Hirschman Index doubled from 1 January 2015 to 1 January 2020, i.e., the banking services market's concentration level went from low to medium.

From the point of view of the competition's qualitative parameters, it should be noted that currently, most medium and small banks find themselves in unequal competitive conditions, due to the lack of access to cheap resources, in particular refinancing programs. That forces them to maintain high capital adequacy by reducing business profitability, and this reduces their competitiveness. At the same time, Ukraine is among the top 10 countries in Europe regarding the number of Internet banking users. Besides, due to the low penetration of banking services in the regions, they have a high potential for Internet audience growth in the future (Shmihelska, 2014). That opens up great opportunities for the banks, in particular small ones. Therefore, the further development of the banking system of Ukraine should be justified in the direction of innovations. In recent years, there has been the formation of Internet banks, or neobanks, in the world's leading countries (a new, innovative group of banking institutions). The first neobanks appeared in global markets in 2004, and during the period 2004-2015, 34 banks were established compared to 45 banks in the last three years (2016-2019). The largest number of neobanks is within the EU banking system, which follows the United States. Neobanks are also present in Brazil, Singapore, UAE, South Africa, Canada, Kenya, Nigeria, China, Hong Kong, India, Russia, Australia, Mexico, Norway, Great Britain, the British Virgin Islands, and Malta.

The first neobanks appeared in the UK after the financial crisis. Fighting the heavy financial losses, banks could no longer lend money to each other. Thus, the government changed the situation by allowing neobanks to accumulate capital and build an Internet infrastructure before obtaining a full banking license. That led to a boom in their operations, which allowed companies (such as Revolut and Monzo) to compete with traditional banks. As these new banks became very popular, the trend quickly spread around the world. Neobanks are now regulated in the same way as traditional banks, and they have become a profitable business model in North America and China (Finsmes, 2020). Neobanks in Australia are currently developing in a similar pattern: large banks or other corporations with credit or another financial license firstly develop and launch cash applications that could eventually accumulate equity and then obtain a separate banking license. Presently there are the following cash applications in Australia:

1. Hay - a money application that offers customers a card, account, and mobile application. It aims to obtain a banking license. Then, it will be able to offer traditional banking products, such as a current bank account, savings account, etc.; 
G., Karcheva, N., Shvets, K., Dalgic, N., Dalevska. Innovative Approaches to the Assessment of Banking Competition in Ukraine in Terms of Digital Transformation

2. Douugh - a cash application in the form of a financial control center with a personal assistant for all funds. This application aims to improve the financial situation of the country's population through its program and a card account issued by a partner bank;

3. Pelikin - a cash application specifically designed for travel and customer cash. Currently, the cards are also issued by two partner banks;

4. QPay - an application created for students to better manage their budget and payments. It also cooperates with another financial institution to issue cards;

5. Revolut is a fintech in the UK that recently offers to open travel accounts.

In addition to the above cash applications, the country already has full-fledged neobanks in two versions: four banks have a separate license ( 86,400 , Judo Bank, Volt Bank, Xinja), and one is established as a subsidiary of a traditional bank and operates under its license (Up Bank). Another reason for the emergence of the neobanks in the world could be called the need to meet the growing demand of consumers for simpler, more convenient services on the Internet and mobile banking. Therefore, such banks immediately received their customer base segment. Therefore, today in the UK and Northern Europe, one in four under the age of 37 uses the services of a digital bank or neobank (Ciobanu, 2020). The demand for remote banking services is particularly high due to quarantine in the country when banks have to take care of the positive financial results of their activities and the health of their customers and employees. As a result, it turned out that most large banks are fully technologically ready to move to the remote service regime. Still, some banks, in most cases smaller ones -do not have the appropriate technological base. Therefore, there is a risk of moving customers to the largest banks, which in turn will increase the imbalance and increase the monopoly in the banking system of Ukraine. Thus, it is necessary to consider the creation of digital banks (or neobanks) as part of the corporation's goal of existing large banks in Ukraine and as individual institutions of the banking system of Ukraine. It will positively affect the banking system's competition level and the development of financial technologies and innovations. Table 4 presents the advantages and disadvantages of launching the neobanks.

Table 4. Advantages and disadvantages of neobanks

\begin{tabular}{|c|c|c|}
\hline Advantages & Disadvantages & $\begin{array}{c}\text { Ability to address the } \\
\text { shortcoming }\end{array}$ \\
\hline $\begin{array}{l}\text { 1. Low transaction costs, resulting } \\
\text { from which neobanks could offer } \\
\text { competitive rates and minimum } \\
\text { commissions. }\end{array}$ & $\begin{array}{l}\text { 1. Branch Services -Neobanks } \\
\text { may not always offer branch } \\
\text { services, while some customers } \\
\text { prefer branches when dealing } \\
\text { with large loans, such as a } \\
\text { mortgage or personal loan. }\end{array}$ & $\begin{array}{l}\text { Some neobanks have already } \\
\text { expanded their services to } \\
\text { granting mortgages in the } \\
\text { developed countries (for } \\
\text { example, Bank } 86400 \text { in } \\
\text { Australia). However, the } \\
\text { application is through a broker } \\
\text { (an independent financial advisor } \\
\text { who receives agency fees from } \\
\text { the bank), i.e., physical meetings } \\
\text { with a loan representative take } \\
\text { place to obtain large loans. }\end{array}$ \\
\hline $\begin{array}{l}\text { 2. Have unquestionable experience } \\
\text { with digital applications, which } \\
\text { allows customers to access new } \\
\text { features from their applications such } \\
\text { as the ability to get instant approval } \\
\text { of loan applications, using various } \\
\text { subscriptions through applications, } \\
\text { access savings tools, track costs, }\end{array}$ & $\begin{array}{l}\text { 2. Reliability. Although neobanks } \\
\text { must undergo the same } \\
\text { regulatory and licensing } \\
\text { processes as any other bank, } \\
\text { they do not have many years of } \\
\text { experience as traditional banks. } \\
\text { Depending on the client's }\end{array}$ & $\begin{array}{l}\text { Uncertain customers should be } \\
\text { reassured that neobanks, like } \\
\text { traditional banks, are members } \\
\text { of the deposit guarantee system. }\end{array}$ \\
\hline
\end{tabular}


G., Karcheva, N., Shvets, K., Dalgic, N., Dalevska. Innovative Approaches to the Assessment of Banking Competition in Ukraine in Terms of Digital Transformation

\section{have a more personal understanding \\ of the overall financial situation for users and the latest payment \\ solutions, including digital wallets and virtual cards \\ 3. Cost tracking. Neobanks could use artificial intelligence to track user's spending behavior and even send alerts if a customer is going to spend money before the day of a programmed payment}

\section{Current bank balances - neobanks could potentially show exactly how much money a customer could spend in real-time}

worldview, this could be an advantage or a disadvantage

3. A small range of banking services in the beginning.

Existing traditional banks offer everything from current accounts to home loans and car insurance. Although neobanks plan to expand their product variety, all of these options may not be available in their early years
Founded in July 2019, the neobank «86400» in Australia in March 2020 has already started to offer mortgages to the customers, so it could be argued that not all of the neobanks follow the same path of development

Sources: developed by the authors.

Hence, the potential launching of the neobanks in Ukraine has more advantages than disadvantages. Proof of this is the activity of Monobank in Ukraine, which could be considered as a neobank. Monobank operates under the license of Universal Bank.

Thus, increasing the competition level in the banking sector as a result of the launching of the digital banks could be one of the ways to reduce interest rates and commissions, the penetration of the banking intermediation in all regions of the country, improving the efficiency of the banking system of Ukraine. The creation of neobanks will respond to the current challenge of the pandemic and the expected demand of young people to increasingly use online banking for these benefits to move to the digital level. Such fullfledged reliable institutions will help support the state's economy by providing the majority of the population and businesses with fast, high-quality, cheap banking services.

Conclusions. The obtained results indicated that the banking sector of Ukraine is characterized by monopolistic competition, which is characterized by increasing concentration in state banks' markets. In this regard, it is important to take effective measures regarding reducing the share of the state-owned banks in the banking sector of Ukraine. Notably, the banking competition level assessment by innovative approaches (which consists of the integrated usage of the structural and non-structural methods and developing a modified Panzar-Rosse model, which considers traditional variables stability indicators) provides deeper, more accurate, and comprehensive results.

Thus, it could be used for analyzing the level of competition in Ukraine in the future. One of the promising ways of the institutional development of the banking system of Ukraine, which will improve competition in the banking market, is the launching of new institutions - neobanks, as a part of the goal of the corporations of existing institutions and as the separate institutions. Therefore, the question now arises for the regulators to develop appropriate regulatory and information fields to support such innovative banks' establishment and operation. For example, the EU has adopted the Directives relating to banking on the Internet before launching the first neobank. In recent years, innovation is ahead of the world's regulatory field, which complicates the supervisory function's implementation and the implementation of the innovations itself. Australia has recently adopted additional regulations on the financial sector's technologies, regulating these activities' specific features. For example, the Data Encryption Act was 
G., Karcheva, N., Shvets, K., Dalgic, N., Dalevska. Innovative Approaches to the Assessment of Banking Competition in Ukraine in Terms of Digital Transformation

passed, requiring Internet companies that use encryption to have a «back door» key if access to the Australian government is required. Another major legislative and regulatory change is the General Data Protection Regulation (GDPR), which is now part of the compliance requirements for doing business in and with the European Union.

Author Contributions: conceptualization, G. K. and N. S.; methodology, K. D.; software, G. S.; validation, N. S., G. K. and K. D; formal analysis, G. K.; investigation, N. S.; resources, K. D.; data curation, G. K.; writing-original draft preparation, N. S.; writing-review and editing, K. D.; visualization, G. K.; supervision, N. S.; project administration, K. D.; funding acquisition, N. S.

\section{References}

Akins, B., Li, L., Ng, J., \& Rusticus, T. O. (2014). Bank Competition and Financial Stability: Evidence from the Financial Crisis. School of Accountancy Research Paper Series, 2(2). [Google Scholar] [CrossRef]

Amidu, M., \& Wolfe, S. (2013). Does bank competition and diversification lead to greater stability? Evidence from emerging markets. Review of Development Finance, 3(3), 152-166. [Google Scholar] [CrossRef

Bank of England (n.d.). Why is competition important in banking? Retrieved from [Link]

Barros, F., \& Modesto, L. (1999). Portuguese banking sector: a mixed oligopoly?. International journal of industrial organization, 17(6), 869-886. [Google Scholar] [CrossRef]

Beck, T. (2008). Bank competition and Financial stability: Friends or Foes? World Bank. Retrieved from [Link].

Berger, A. N., \& Hannan, T. H. (1989). The price-concentration relationship in banking. The Review of Economics and Statistics, 291-299. [Google Scholar] [CrossRef]

Berger, A. N., Demirgüç-Kunt, A., Levine, R., \& Haubrich, J. G. (2004). Bank concentration and competition: An evolution in the making. Journal of Money, Credit and Banking, 433-451. [Google Scholar]

Bikker, J. A., \& Haaf, K. (2002). Competition, concentration and their relationship: An empirical analysis of the banking industry. Journal of banking \& finance, 26(11), 2191-2214. [Google Scholar] [CrossRef]

Bikker, J. A., Shaffer, S., \& Spierdijk, L. (2010). Assessing competition with the Panzar-Rosse model: The role of scale, costs, and equilibrium. Review of Economics and Statistics, 94(4), 1025-1044. [Google Scholar] [CrossRef]

Bikker, J., Spierdijk, L., \& Finnie, P. (2006). Misspecifiation of the Panzar-Rosse Model: Assessing Competition in the Banking Industry (No. 114). Netherlands Central Bank, Research Department. [Google Scholar]

Boone, J. (2000). Competition. CEPR DP 2636. Retrieved from [Link]

Bresnahan, T. F. (1982). The oligopoly solution concept is identified. Economics Letters, 10(1-2), 87-92. [Google Scholar] [CrossRef]

Casu, B., \& Girardone, C. (2006). Bank competition, concentration and efficiency in the single European market. The Manchester School, 74(4), 441-468. [Google Scholar] [CrossRef]

Cetorelli, N., \& Gambera, M.. (2001). Banking Market Structure, Financial Dependence and Growth: International Evidence from Industry Data FRB. Chicago Working Paper No. 99-08, 56(2). [CrossRef]

CGFS. (2018). Structural changes in banking after the crisis. CGFS Papers, 60. Retrieved from [Link]

Ciobanu, M. (2020). Comparing neobank markets: Europe vs Latin America. Retrieved from [Link]

Demsetz, H. (1973). Industry structure, market rivalry, and public policy. The Journal of Law and Economics, 16(1), 1-9. [Google Scholar]

Didenko, I, Kryvych, Y., \& Buriak, A. (2018). Evaluation of Deposit Market Competition: Basis for Bank Marketing Improvement. Marketing and Management of Innovations, 2, 129-141. [Google Scholar] [CrossRef]

Duncan, D., \& Langrin, B. (2004). Testing for competition in the Jamaican banking sector: evidence from bank level data. Southwestern Journal of Economics, 6(1). [Google Scholar]

Feldkircher, M., \& Sigmund, M. (2017). Comparing market power at home and abroad: evidence from Austrian banks and their subsidiaries in CESEE. Focus on European economic integration Q, 3, 59-77. [Google Scholar]

Finsmes. (2020). What are neo banks and how will they shape the future of finance? Retrieved from [Link].

Hirna, O.I. (2014). Descriptive and model estimates of the banking market of the European Union and Ukraine. Financial space, 4(16), 49-55. [Google Scholar]

Hrytsenko, L. L., Roienko, V., \& Boiarko, I. M. (2018). Institutional background of the role of state in investment processes activation. Financial and credit activities: problems of theory and practice, 1(24), 338-344. [CrossRef]

Karcheva, H. T. (2016). Comprehensive assessment of the competitive environment in the banking sector of Ukraine. Bankivska sprava, 4, 77-90.

Kharazishvili, Y., Kwilinski, A., Grishnova, O., \& Dzwigol, H. (2020). Social Safety of Society for Developing Countries to Meet Sustainable Development Standards: Indicators, Level, Strategic Benchmarks (with Calculations Based on the Case Study of Ukraine). Sustainability, 12(21), 8953. [Google Scholar] [CrossRef] 
G., Karcheva, N., Shvets, K., Dalgic, N., Dalevska. Innovative Approaches to the Assessment of Banking Competition in Ukraine in Terms of Digital Transformation

Kwilinski, A., Vyshnevskyi, O., \& Dzwigol, H. (2020). Digitalization of the EU Economies and People at Risk of Poverty or Social Exclusion. Journal of Risk and Financial Management, 13(7), 142. [Google Scholar] [CrossRef]

Lau, L. J. (1982). On identifying the degree of competitiveness from industry price and output data. Economics Letters, 10(12), 93-99. [Google Scholar] [CrossRef]

Leonov, S. (2009). Investment potential of the banking system of Ukraine. Sumy. DBA UABS NBU.

Lerner, A. (1934). The concept of monopoly and the measurement of monopoly power. V Review of Economic Studies, 1(157), 75

National bank of Ukraine. Retrieved from [Link].

OECD. (2011). Bank Competition and Financial Stability. Retrieved from [Link]

Panzar, J. C., \& Rosse, J. N. (1987). Testing for «monopoly» equilibrium. The journal of industrial economics, 443-456. [Google Scholar] [CrossRef

Peltzman, S. (1977). The gains and losses from industrial concentration. The Journal of Law and Economics, 20(2), 229-263. [Google Scholar] [CrossRef]

Rekunenko, I. I., Hrytsenko, L. L., Boiarko, I. M., \& Kostyrko, R. A. (2019). Financial debt market in the system of indicators of development of the economy of the country. Financial and credit activities: problems of theory and practice, 2(29), 430-439. [Google Scholarl

Reserve bank of Australia (2014). Competition, efficiency and innovation in banking. Retrieved from [Link].

Scorlupina, U.O. (2015). About the methods of assessing the interbank competition in the Russian interbank market. Financial analytics: problems and solutions, 5(239), 54. [Google Scholar]

Shmihelska, Z. (2014). Banking innovations: essence, necessity and development]. Visnyk NBU, 34-41. [Google Scholar]

Sinki, J. (2019). Financial management in a commercial bank and in the financial industry. [Google Scholar]

Strielkowski, W., \& Höschle, F. (2016). Evidence for economic convergence in the EU: The analysis of past EU enlargements. Technological and Economic Development of Economy, 22(4), 617-630. [Google Scholar] [CrossRef]

Titko, J., Kozlovskis, K., \& Kaliyeva, G. (2015). Competition-stability relationship in the banking sector. Systemics, Cybernetics and Informatics, 13(2), 25-31. [Google Scholar]

Vasylieva, T. A. (2015). The assessment of the competition in the credit and deposit markets of Ukraine. Visnyk Ukrainskoi akademii bankivskoi spravy, 2(39), 41-45.

Vives, X. (2016). Competition and stability in banking: The role of regulation and competition policy. Princeton University Press. [Google Scholar]

Vovchak, O. D., Senyshch, P. M., \& Melnyk, T. V. (2019). «Purging» of the banking system: impact on the key performance indicators of banks. Financial and credit activity: problems of theory and practice, 1(28), 16-25. [Google Scholar] [CrossRef]

Zherdetska, L. V. (2016). Development of the banking competition and its impact on the systemic stability in Ukraine. Ekonomika i suspilstvo, 3, 382-387. [Google Scholar]

Zherdetska, L., \& Tatarova, L. (2009). Non-structural models of the evaluation of the competition in the market of banking products and services of Ukraine. Naukovyy visnyk OSEU, 12 (90), 44-53.

Ганна Карчева, д.е.н., профресор, Університет банківської справи, Україна

Наталья Швець, д.е.н., професор, Університет банківської справи, Україна

Каріна Далгич, Університет банківської справи, Україна

Наталія Далевська, д.е.н., доцент, Інститут розвитку міжнародної співпраці, Польща

Інноваційні підходи до оцінки банківської конкуренції в Україні: за умов цифрової трансформації

Ця стаття узагальнює аргументи та контраргументи в межах наукової дискусії щодо аналізу впливу рівня конкуренції на рівень ефективності банківської системи. Основною метою дослідження є комплексна оцінка поточного рівня конкуренції на банківському ринку України та розробка модиффікованої моделі Панзара-Росса, яка враховує особливості банківської діяльності в Україні. Систематизація наукових напрацювань та підходів щодо досліджуваного питання засвідчила про те, що вітчизняні автори, переважно, використовують лише один із методів оцінки рівня конкуренції. Встановлено, що низка наукових робіт, присвячених оцінюванню рівня конкуренції на банківському ринку України, грунтується на даних за докризовий період, які не $є$ актуальними для сучасного стану банківської системи. Так, на разі кількість банків в Україн скоротилась майже вдвічі, а розвиток фінансових інновацій суттєво змінив діяльність банків. Таким чином, актуальність розв'язання наукової проблеми полягає у своєчасному виявленні та усуненні поточної проблеми у банківській системі на основі комплексного оцінювання рівня банківської конкуренції. Окрім цього, автори відмітили, що значення даного питання зросло після суттєвого скорочення кількості банківських установ в Україні в останні роки, а також у результаті зміни структури банківської системи України під впливом фінансових інновацій. Для досягнення поставленої мети, дослідження здійснено в наступній логічній послідовності: 1) розглянуто наявний науковий доробок щодо означеної тематики; 2) визначено та охарактеризовано наявні методи оцінювання конкуренції на банківському ринку; 3) описано запропоновану модифікацію методів, яків враховують особливості діяльності банків в Україні; 4) висвітлено результати емпіричних досліджень за обраними й модифікованими методами дослідження рівня банківської конкуренції; 5) сфформовано пропозиції щодо покращення банківської конкуренції в Україні. Періодом дослідження обрано 2019 рік. Об'єктом дослідження є банківська 
G., Karcheva, N., Shvets, K., Dalgic, N., Dalevska. Innovative Approaches to the Assessment of Banking Competition in Ukraine in Terms of Digital Transformation

система України. Результати емпіричного аналізу засвідчили, що для банківського сектору України характерною $\epsilon$ монополістична конкуренція, концентрація якої зростає на ринку державних банків. Дослідження емпірично підтверджує та теоретично доводить, що скорочення кількості банків та вплив цифрової трансформації сприяли зростанню ринкової влади низки банків України. За результатами дослідження запропоновано низку інноваційних підходів, які можуть бути використані для оцінювання рівня банківської конкуренції в Україні. Отримані результати можуть бути корисними для власників банків при формуванні стратегії розвитку необанків, на які існує високий попит у банківській системі в Україні.

Ключові слова: банківська система, ефективність, інновації, ринок, конкуренція. 